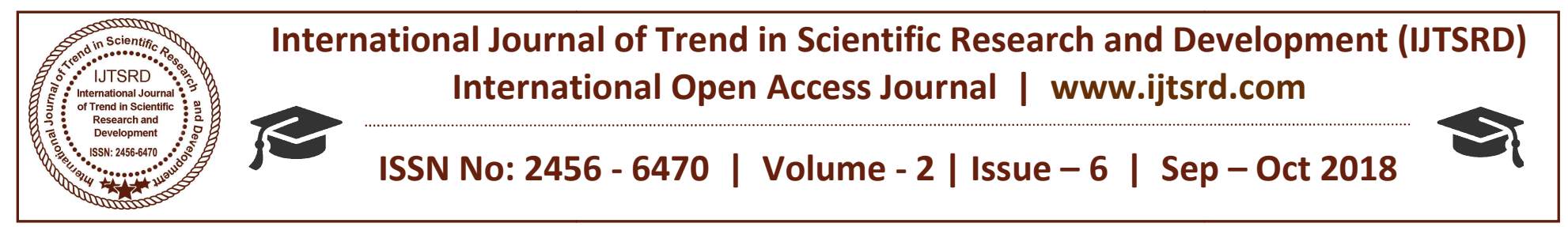

\title{
Analysis of Physio-Chemical Properties of Mangosteen Rind Extract from Industrial Waste
}

\author{
Sasikala. S \\ Research Scholar, \\ Bharathiar University, \\ Coimbatore, Tamil Nadu, India
}

\author{
Dr. Radhaisri. S \\ Associate Professor, \\ Department of Food \& Nutrition, \\ PSG College of Arts and Science, \\ Coimbatore, Tamil Nadu, India
}

\author{
Deeptha Kumar \\ Research \& Development \\ Executive, Oriens Global \\ Marketing PVT Ltd, \\ Chennai, Tamil Nadu, India
}

\begin{abstract}
The food industry generates a large amount of wastes or by-products annually around the world from a variety of sources. By-products are the main raw materials for the formulation of functional foods in the food industry. Fruit and vegetable wastes are produced in large quantities in markets and their recovery could be employed for the production of nutraceuticals and functional foods. The food waste can be reduced by extraction of high-value components such as proteins, flavor compounds, and phytochemicals which can be re-used as nutraceuticals ingredients. High potential nutraceutical from underutilized fruit parts was selected for the study. Mangosteen fruit rind contains xanthones which have antioxidant, anti-proliferation and anti-microbial activity that are not reported in any other fruit. The pericarp or fruit hull of mangosteen rich in Xanthones from industrial waste were selected for the study. The physio-chemical properties of mangosteen rind were analyzed. The resultant properties of mangosteen rind were compared with the commercial sample, which complies with the specification.
\end{abstract}

Keywords: Industrial waste, mangosteen, physiochemical properties, nutraceutical

\section{INTRODUCTION}

Fruit and vegetable wastes (FVW) are produced in large quantities in markets and their recovery could be employed for the production of nutraceuticals and functional foods. One of the most beneficial approaches is to recover the bioactive constituents, especially the phenolic compounds, making full use of them in the food, pharmaceutical as well as the cosmetics industry.

Plants are recognized as major sources of natural nutrients. They contain a variety of substances called "phytochemicals". Among various parts of the plant, fruits are important as a natural antioxidant source. The special attention is given to focus inexpensive or residual sources from agricultural industries. The epicarp i.e. peels and seeds of fruits are the powerful natural antioxidants which are the high amount of wastage in the food industry. Among the different fruit waste, mangosteen peel has better content of natural phenolic antioxidants. The mangosteen peel contains bioactive substances, such as phenolic acids and flavonoids, which possess biological and medicinal properties. The aim of the research study is to extract the nutraceuticals from the mangosteen rind and analysis its Physio-chemical properties.

Mangosteen (Garcinia mangostana L.) is a tropical tree native to Southeast Asia that produces a fruit whose pericarp contains a family of tricyclic isoprenylated polyphenols referred to as xanthones. Numerous in-vitro studies have shown that these xanthones possess anti-oxidant, anti-proliferative, proapoptotic, anti-inflammatory and anticarcinogenicactivities (Orozco and Failla, 2013). Mangosteen has recently gained popularity as an alternative medicinal product and there are over 50 natural xanthones reported in mangosteen (Chaverri et al 2008, Zarena and Sankar 2009).

$\alpha$ and $\gamma$-Mangostin are the common prenylatedxanthones present in the fruit of the 
mangosteen tree. They have been reported to possess numerous bioactivities that have provided the impetus for use of mangosteen products as nutraceuticals and dietary supplements. The health-promoting benefits of mangosteen are dependent on delivery of the xanthones to target tissues (Obolskiy et al 2009).
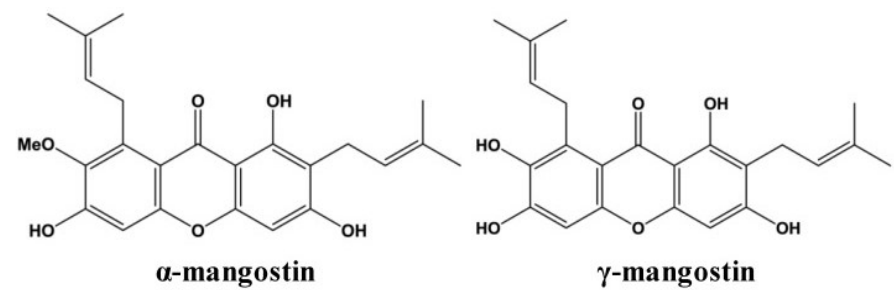

Mangosteen peel contains a large number of xanthones (especially $\alpha$-mangosteen). It has been used as traditional medicine and is popularly applied to constitute cosmetic and pharmaceutical products. However, there is only a little information available for quality and quantity determination of amangosteen in mangosteen (Yodhnu et al 2009). Because $\alpha$-mangostin represents the majority of the clinical benefits of this herbal medicine, it is reasonable and logical to determine the concentration of $\alpha$-mangosteen as a chemical marker for the quality control of $G$. mangostana and its products, which usually is the only xanthone ingredient quantitymarked in the label (Zarena and Sankar, 2009).

\section{METHODOLOGY}

\section{Selection of Sample}

Mangosteen fruit was purchased from the local market in Chennai.

\section{Chemicals, Glassware, and Reagents}

Test tube, Incubator Shaker, High-speed blender, Centrifuge, Conical Flask, Beaker, Ethanol, distilled water

\section{Mangosteen Extract}

The edible part of the fruit, constituting the aril, which is freshly eaten, dried, frozen or canned only amounts to about 30 percent of its fresh weight, while the pericarp and seed are considered as waste (Okonogi et al 2007). The Fruit rind of Mangosteen has been used as a traditional medicine for antidiarrhea, antidysenteric and treatment of wounds(Gritsanapan and Chulasiri, 1983). It is reported to contain several groups of phenolic compounds such as tannins, flavonoids, and xanthones supporting its traditional use (Fransworth and Bunyapraphatsara, 1992 and $\mathrm{Yu}$ et al 2007). A major xanthone in the fruit rind is $\alpha$ - mangosteen (Walker, 2007 and Chen et al 2008). Due to the hydroxyl groups, attached to the unsaturated heterocyclic xanthone core, xanthones exert high antioxidant activity (Martinez et al 2011). Mangosteens are free-radical scavengers and inhibit the oxidation of Low-Density Lipoproteins (LDL-C) cholesterol (Williams et al 1995 and Mahabusarakam et al 2000). Mangosteen Fruit Extract is popularly used as a food supplement due to antioxidant activity. Recently Garciniamangostana Fruit rind extract has become popular, used as a dietary supplement, herbal medicine and cosmetic combination. The Biological quality of mangosteenderived products is based on the contents of $\alpha$ - mangosteen, tannins and other phenolic compounds (Pothitirat et al 2010).

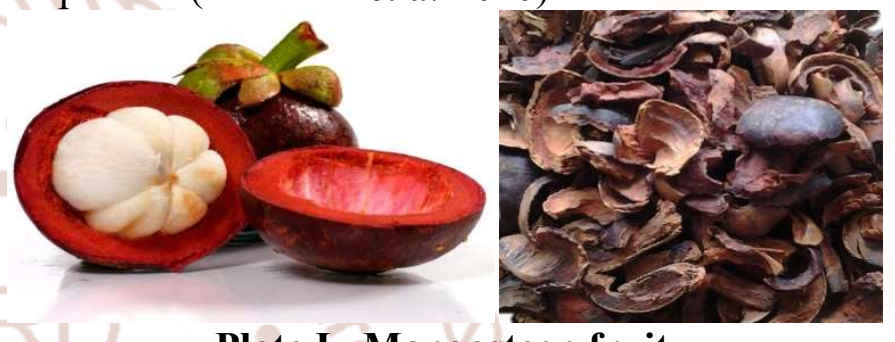

Plate I-Mangosteen fruit

The yield of $\alpha$-mangostin from the dried pericarp was approximately 0.4 percent $(\mathrm{w} / \mathrm{w})$ (Torrungruang and Chutimaworapan, 2007). Low antioxidant activity in hexane extract may be due to the polar nature of compounds which are not completely extracted in hexane extract whereas acetone and ethyl acetate extracts are able to percolate the matrix thus enhancing the solubility (Zarena and Sankar, 2009).

Higher absorbance indicated higher activity; ethyl acetate extract showed strongest antioxidant property, ethyl acetate and acetone extract showed good antioxidant activity except in the chelating assay the extraction yield and antioxidant potential of the compounds in the extract is strongly dependent on the solvent polarity. Our results indicate the active constituents in mangosteen have intermediate polarity and hence can be easily extracted by ethyl acetate or acetone as the extraction solvent. The extraction of mangosteen pericarp in ethyl acetate extract showed maximum antioxidant activity and free radical scavenging activities in vitro conditions (Zarena and Sankar, 2009).

The xanthones in the different solvents (ethyl acetate, acetone, and hexane), was investigated by means of high-performance liquid chromatographyelectrosprayionization/mass spectrometry (HPLC ESI/MS) technique. The maximum yield was obtained 
from ethyl acetate when compared to minimum yields of hexane extracts respectively (Zarena and Sankar, 2009).

According to Nabandith et al 2004, ethyl acetate used as a solvent to extract the mangosteen from the Garciniamangostana reported the extract was composed of 77.8 percent $\alpha$ - mangosteen and 15.9 percent $\gamma$ - mangosteen

It has been reported that dichloromethane was the most suitable solvent for extraction of $\alpha$-mangostin from Garcinia mangostana pericarps (Pothitirat, Chomnawang, and Gritsanapan, 2010). However, the use of dichloromethane, halogenated hydrocarbon as a solvent for extraction is restricted due to its toxicities (Calepa, 2000) and limitations on its use in the development of herbal products. Nowadays, industrial regulations require a diminished consumption of petrochemical solvents and volatile organic compounds. Moreover, the absence of risk during extraction and the safety of the ingredients used are a major concern and have drawn attention towards the need to use a greener solvent (Rombaut et al 2014). Alternative green solvents, a renewable resource produced from biomasses such as wood, starch, vegetable oils or fruits are high power, biodegradable, low toxicity, and low flammability. Extensive studies have shown the importance and the reported potential of green solvents that could be alternatively used instead of the petrochemical solvents, e.g. extraction of fat and oils from the rape seed using MeTHF instead of hexane (Sicaire et al 2015) and extraction of oil from microalgae using D-limonene instead of hexane (Tanzi et al 2012). Ethyl acetate will be promising alternative solvents for the extraction of $\alpha$ mangosteen (Bundeesomchok, 2016). Considering this ethyl acetate was used to extract mangosteen rind.

\section{Method of Extraction - Mangosteen Rind}

Mangosteen fruit was purchased from the local market in Chennai. The fruits were cleaned and the edible part was removed. The fruit rinds were cut into small pieces and dried in a hot oven at $50{ }^{\circ} \mathrm{C}$ for $72 \mathrm{~h}$. The dried samples were ground into powder, passed through a sieve (20 meshes). The samples were separately kept in airtight container and protected from light until used.

The mangosteen rind was extracted by ethyl acetate and xanthone-rich extract was obtained. Extractions were carried out for $2 \mathrm{~h}$ that include initial boiling for 30 min. After filtering the extract through Whatman No. 1 paper, each of the filtrates was concentrated using rota evaporator at $40{ }^{\circ} \mathrm{C}$, the weight of the extract was noted and the final volume was made up to $25 \mathrm{ml}$ in a volumetric flask. The extract was kept in airtight bottles and stored in a freezer at $20{ }^{\circ} \mathrm{C}$. The extract was filtered with a muslin cloth. The Bio-based solvent "Green Solvent" is used for the extraction (Rojo et al 2012).

\section{RESULTS AND DISCUSSION}

The moisture content of mangosteen rind extract was 7.91 percent and the ash content was 2.49 percent. The Xanthones percentage in the extract powder was detected by HPLC method (Zarena and Sankar, 2009).

Table I: Physical and Chemical Characteristics of Mangosteen Rind Extract

\begin{tabular}{|c|c|}
\hline Tests & Results \\
\hline Description & Brown Colour Powder \\
\hline Odor & Characteristic \\
\hline Taste & Astringent \\
\hline Ash (\%) & 2.49 \\
\hline Moisture (\%) & 7.91 \\
\hline
\end{tabular}

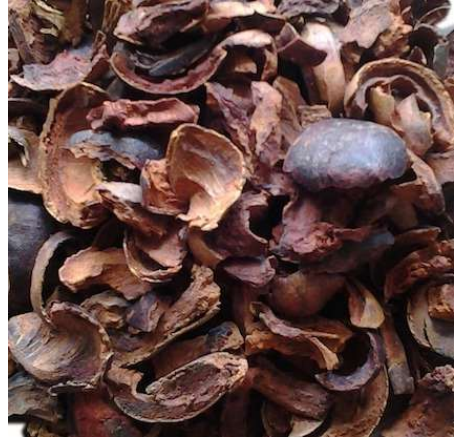

Mangosteen rind

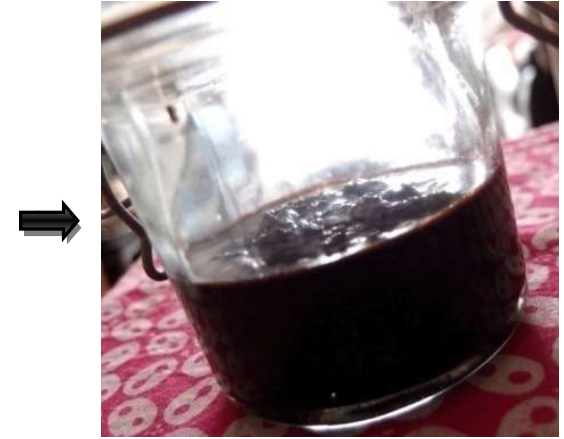

Liquid solvent extract

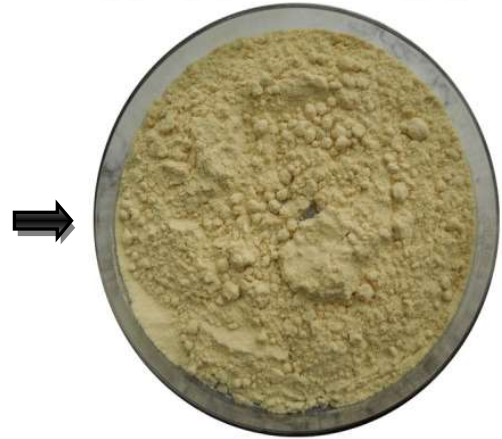

Solid extract (powder)

Plate II: Extraction Picture - b) Mangosteen Rind 
The extraction of Mangosteen rind was spray dried and it is brown in color, astringent in taste. The Mangosteen rind extract is soluble in water. The Mangosteen rind extracted was compared with some commercial sample and it's similar in nature.

\section{CONCLUSION}

Food wastes or by-products convert to the functional food ingredients it is the healthy trends in the food industry. Waste management is one of the major parts of food industries. The large volume of the low-cost by-product gives the economical advantage of its potentially valuable components and environmental benefits. Mangosteen rinds were selected as an industrial waste for assessing the physio-chemical properties. The selected mangosteen rind was similar to the reviewed commercial sample. This mangosteen rind can be utilized for the usage in the nutraceutical products.

\section{Acknowledgment}

The authors would like to express their deepest gratitude to P. Karthikeyan, CEO, S. Moulishankar, COO, S. Suman, CFO Oriens Global Marketing (P) Ltd, India for financial support for this study and permitting us to conduct this study. Our heartfelt thanks go to the Parthiban Subramanian/for his guidance and support.

\section{REFERENCE}

1. Bundeesomchok, K., Filly, A., Rakotomanomana, N., Panichayupakaranant, P., Chemat, F (2016), Extraction of a-mangosteen $S \mathrm{~S}$ from Garciniamangostana L. using alternative solvents: Computational predictive and experimental studies, LWT - Food Science and Technology, 65, 297-303.

2. Calepa (California environmental protection agency), (2000), Public health goals for chemicals in drinking water: Dichloromethane (methylene chloride, DCM), Available http://oehha.ca.gov/water/phg/pdf/dcm.pdf (accessed 09.04.15).

3. Chaverri, J., Rodriguez, N., Ibarra, M., Rojas, J, M (2008), Medicinal properties of mangosteen (Garciniamangostana), Food and Chemical Toxicology, 46, 3227-3239.

4. Chen, L.G., Yang, L. L., Wang, C.C (2008), Antiinflammatory activity of mangostins from Garciniamangostana, Food and Chemical Toxicology, 46, 688-693.
5. Fransworth, N.R and Bunyapraphatsara (1992), Thai Medicinal plants, Recommended for primary Health Care System, Bangkok, Prachachon Company, 160-162.

6. Gritsanapan, W and Chulasiri, M (1983), A preliminary study of anti diarrheal plants: I. Antibacterial activity, Mahidol university journal of pharmacology science, 10, 119-112.

7. Mahabusarakam, W., Proudfoot, J., Taylor, W., Croft, K (2000), Inhibition of lipoprotein oxidation by prenylatedxanthones derived from mangostin, Free Radical Research, 33, 643-659.

8. Martinez, A., Galano, A., Vargas, R (2011), Free radical scavenger properties of alpha-mangostin: Thermodynamics and kinetics of hat and raf mechanisms, Journal of Physical Chemistry A, $115,12591-12598$.

9. Nabandith, V., Suzui, M., Morioka, T., Kaneshiro, T., Kinjo, T., Matsumoto, K., Akao, Y., Iinuma, M., Yoshimi, N (20014), Inhibitory effects of crude alpha-mangostin, a xanthone derivative, on two different categories of colon preneoplastic lesions induced by 1, 2-dimethylhydrazine in the rat. Asian Pacific Journal of Cancer Prevention, 5, $433-438$.

10. Obolskiy, D., Pischel, I., Siriwatanametanon, N., Heinrich, M (2009), Garciniamangostana L A phytochemical and pharmacological review, Phytotherapy Research, 23, 1047-1065.

11. Okonogi, S., Duangrat, C., Anuchpreeda, S., Tachakittirungrod, S., Chowwanapoonpohn, S (2007), Comparison of antioxidant capacities and cytotoxicities of certain fruit peels, Food Chemistry, 103, 839-846.

12. Orozco, F.G and Failla, M.L (2013), Biological Activities and Bioavailability of MangosteenXanthones A Critical Review of the current evidence, 5(8), 3163-3183.

13. Pothitirat, W., Chomnawang, T.M., Supabphol, R., Gritsanapan, W ( 2010), Free Radical Scavenging and anti-acne activities of mangosteen fruit rind extracts prepared by different extraction methods, Journal of Pharmaceutical Biology, 48(2), 182-186.

14. Pothitirat, W., Chomnawang, T.M., Supabphol, R., Gritsanapan, W ( 2010), Free Radical Scavenging and anti-acne activities of mangosteen fruit rind extracts prepared by different extraction 
methods, Journal of Pharmaceutical Biology, 48(2), 182-186.

15. Rombaut, N., Fabiano-Tixier, A, S., Bily, A., Chemat, F (2014), Green extraction processes of natural products as tools for the biorefinery. Biofuels, Bioproducts and Biorefining, 8, 530544.

16. Sicaire, A.G., Vian, M., Fine, F., Joffre, F., Carre, P., Tostain, S (2015), Alternative bio-based solvents for extraction of fat and oils: solubility prediction, global yield, extraction kinetics, chemical composition and cost of manufacturing, International Journal of Molecular Sciences, 16, 8430-8453.

17. Tanzi, C.D., Vian, M., Ginies, C., Chemat, F (2012), Terpenes as Green Solvents for Extraction of Oil from Microalgae, Molecules, 17, 81968205.

18. Torrungruang, K., Chutimaworapan S (2007), Effect of mangosteen pericarp extract on cell viability in human gingival fibroblasts, Chulalongkorn University Dental Journal, 29, 7582.

19. Walker, E, B (2007), HPLC analysis of selected xanthones in mangosteen Fruit, Journal of Separation Science, 30, 1229-1234.
20. Williams, P., Ongaskul, M., Proudfoot, J., Croft, K., Beilin, L (1995), Mangostin Inhibits the Oxidative Modification of Human Low Density Lipoprotein, Free radical research, 23(2), 175-84.

21. Yodhnu, S., Sirikatitham, A., Wattanapiromsakul, C (2009), Validation of LC for the Determination of $\alpha$-Mangosteen in Mangosteen Peel Extract: A tool for Quality Assessment of Garciniamangostana L, Journal of Chromatographic Science, 47, 185-189.

22. Yu, L., Zhao, M., Yang, B., Zhaq, Q., Jiang, Y (2007), Phenolics from Hull Of Garciniamangostana Fruit And Their Antioxidant Activities, Food Chemistry, 104, 176-181.

23. Zarena, A, S and Sankar, K.U (2009), Screening of xanthone from mangosteen (GarciniamangostanaL.) peels and their effect on cytochrome c reductase and phosphomolybdenum activity, Journal of Natural Products, 2, 23-30.

24. Zarena, A.S and Sankar, K.U (2009), Study of Antioxidant Properties From Garciniamangostana L. Pericarp Extract, Acta ScientiarumPolonorumTechnologia Alimentaria, 8(1), 23-34. 